\title{
DEBTOR PROTECTION IN THE EXECUTION OF FIDUCIA SECURITIES
}

\author{
Ratih Mega Puspasari \\ Sultan Agung Islamic University \\ ratihmega789@gmail.com \\ Muhammad Ngazis \\ Sultan Agung Islamic University \\ Aziz86@unissula.ac.id
}

\begin{abstract}
In its development, economic needs and economic pressure cannot release every human being from his dependence on loan guarantee institutions. Fiduciary collateral institutions are not excluded, however, in its development, the installment payment process often fails, requiring that fiduciary collateral be executed to be taken by creditors, while the method of execution often uses debt collection services with a violent approach. The approach method used in this paper is an empirical juridical method where legal issues are analyzed from the normative and empirical aspects.
\end{abstract}

Keywords: Credit Agreement; Fairness; Standard Clause;

\section{A. INTRODUCTION}

Currently, unknown transactions such as leasing agreements, leasing, factoring, and other transactions are in the same breath as these transactions. In this case, lease agreements and new sale and purchase agreements develop as a result of business habits and needs in the community domain. ${ }^{1}$

In Indonesia, many people are successful in their work so that they can make ends meet, but not all people can be successful in their jobs so that if they are unable to fulfill their daily needs, people have to look for other efforts such as selling the valuables they have. By selling valuable goods, people will get a certain amount of money that can be used to meet their needs. But with the sale of valuables the risk is that the goods cannot be recovered because they have changed hands and become the property of other people. ${ }^{2}$

To achieve the highest profit, producers or business actors must compete among business actors with their business behavior that can harm consumers. Tight competition can change behavior towards unfair

1 Vienna P. Setiabuddi, Default Vehicle Hire Purchase Agreement, Unsrat Law Journal, Vol. 1, Number 1, 2013, page. 95.

2 M. Taufich Hidayat, Martin Roestamy, and Endeh Suhartini, Development of Fidusia Models on Deposit Counter from PT Pegadaian Persero To the Debtor, Jurnal Living Law, Vol. 11, No. 2, 2019 page. $160-171$ 
competition because business actors have conflicting interests among business actors. This unhealthy competition, in turn, can harm consumers. ${ }^{3}$

It seems that to overcome capital difficulties for small entrepreneurs in particular and medium-sized entrepreneurs in general, at this time a forum has been created to be able to help capital for these small entrepreneurs, namely through the Fiduciary Guarantee regulated by Law No. 42 of 1991 concerning Fiduciary Guarantee, namely as collateral for movable property. With this Fiduciary guarantee, the entrepreneur does not need to hand over the goods that are used as collateral, the goods can still be used for the smooth running of his business. In this fiduciary there is the trust from the owner of the capital to the users, for example, taxi entrepreneurs, taxi cars are still operated. ${ }^{4}$

The loan is through a loan secured by fiduciary creditors, which in this case is mostly related to the sale and purchase of motorized vehicles and cars. This financing company or creditor is an institution that provides financing or funding for the purchase of goods or businesses whose payments can be made periodically.

Fiduciary guarantees are conventional products that are applied to protect creditors in particular. When the debtor defaults, the creditor can ask for compensation from the debtor through the execution of a fiduciary guarantee. With fiduciary registration, execution of collateral can be carried out immediately without waiting for a court ruling. Such conditions make it easier for financial institutions to collect compensation from financing provided to customers. $^{5}$

In the financing agreement, usually, the creditor includes the words guaranteed by fiduciary, which means that in the credit agreement there is a fiduciary guarantee agreement that burdens the object being financed as collateral for repayment of debt in the event of bad credit or default.

In addition, the imposition of objects that are used as fiduciary security must be registered at the fiduciary registration office as regulated in Article 11 paragraph (1) of Law Number 42 of 1999 concerning Fiduciary Security. Registration of fiduciary security is carried out no later than 1 (one) month after the credit or financing agreement is made. A fiduciary guarantee certificate must be drawn up at a notary's office as stipulated in Article 5 paragraph (1) of the Fiduciary Guarantee Law. Registering a fiduciary guarantee will make it easier for creditors to execute fiduciary guarantees in the event of bad credit or default. However, the facts found in the field show that many creditor companies did not register fiduciary guarantees, and in practice confiscation of collateral by creditors was carried out by force without prior notification to the debtor.

This raises a legal problem, in which the seizure of the guarantee unilaterally by coercion without the existence of a fiduciary guarantee deed

3 Janus Sinabalok, Consumer Protection in Indonesia Law, Citra Aditya Bakti, Bandung, 2014, page. 2.

4 M. Yasir, Legal Aspect of Fiduciary Guarantee, SALAM; Jurnal Sosial \& Budaya Syar-i

5 Muhammad Maksum, Application of Fiduciary Guarantee in Sharia Financing Contracts, Jurnal Cita Hukum, Volume 3 Number 1 Year 2015, page.55 
is contrary to the applicable provisions in the Fiduciary Guarantee Law and the Chief of Police Regulation No. 8 of 2011. Apart from that, the problem that exists is who is entitled to the fiduciary security if the debtor is unable to pay credit installments. Regarding the right to execute on items purchased in installments, there are regulatory differences between the Consumer Protection Law and the Fiduciary Guarantee Act.

In the provisions of Article 18 paragraph (1) letters $d$ and $f$ of the Consumer Protection Law, it is prohibited for business actors to include standard clauses in the financing agreement regarding the granting of power over these objects to business actors to reduce service benefits or consumer assets which are the object of sale and purchase. services in case of bad credit or default.

Whereas Article 15 paragraph (3) of the Fiduciary Security Law stipulates that the recipient of fiduciary has the right to sell objects which are used as the object of fiduciary security at his own will. Apart from the Consumer Protection Law and the National Police Regulation No. 8 of 2011, the prohibition of unilateral execution as intended by Article 15 paragraph (3) of the Fiduciary Security Law regarding fiduciary collateral objects is also regulated in the Constitutional Court Decision Number 18 / PUU-XVII / 2019 also prohibits unilateral execution by creditors of debtors in execution fiduciary collateral. With the existence of Article 15 of Law Number 42 of 1999 concerning Fiduciary, it has clearly resulted in an opportunity for the execution of Fiducia collateral which is carried out unilaterally by creditors, this has clearly resulted in injustice for the debtor.

The purpose of this study is to examine and analyze how the implementation of legal protection for debtors in the execution of fiduciary security objects which is carried out unilaterally by the creditor, resulting in injustice for the debtor.

\section{B. RESEARCH METHOD}

The method used in this paper is an empirical juridical method where legal issues are analyzed from the normative and empirical aspects. Analytical descriptive research specification. Research that seeks to describe legal problems, legal systems and to study or analyze them according to the needs of the research concerned. ${ }^{6}$ The data analysis used is qualitative, namely the data obtained, then compiled systematically for further qualitative analysis to achieve clarity of the problem to be discussed. ${ }^{7}$

\section{RESULT AND DISCUSSION}

\section{Fairness in Credit Agreements with Standard Clause}

Fiduciary Guarantee is a follow-up agreement, which means that there is a principal agreement that becomes the parent of the fiduciary guarantee agreement. For example, if the principal agreement is a debt

6 Jawade Hafidz, Law Research Method, Faculty of Law of Islamic University, Semarang, 2009, page. 45

7 Ronny Hanitijo Soemitro, Jurimetric and Legal Research Methodology, Ghalia Indonesia Jakartam, 1990, page.116. 
agreement, then the fiduciary guarantee can be a covenant of the debt agreement. About fiduciary objects, based on Article 20 of the Fiduciary Security Law, it regulates objects that are objects of Fiduciary Security in the hands of whomever these objects are, except for the transfer of inventory objects that are objects of Fiduciary Security.

This article follows the principle of the droit de suite about absolute rights over material. the object which is guaranteed by fiduciary control remains with the debtor. In general, execution is the implementation of a court decision or deed. Execution of fiduciary security is the confiscation and sale of objects used as the object of fiduciary security. ${ }^{8}$

\section{Contract strategy in achieving Justice is contracted}

The Consumer Protection Act has provided guidelines for making standard contracts. It must be admitted that the consumer's position in a standard contract is limited to taking or rejecting the policy offered to him. On this basis, the state is also the party responsible for upholding consumer protection, so that every consumer can feel comfort and security.

A party with a weak position tends to only accept and sign the contents of the agreement because they do not have the bargaining power to change the contents of the contract. If based on the objectives to be achieved by the parties in an agreement, it can be seen that the agreement was made to get an agreement as well as a legal basis for the parties to do or not to do something.

One of the efforts that can be made to achieve fairness in the contract can be efforts to develop and supervise, the responsibility for guidance lies with the government as referred to in Article 29 of Law Number 8 of 1999, namely: the government is responsible for fostering the implementation of consumer protection that guarantees consumer rights and business actors and the implementation of consumer and business actor obligations; guidance by the government on the implementation of consumer protection as referred to in paragraph (1) shall be carried out by the Minister and / or the related technical ministers; the minister as intended in paragraph (2) coordinates the implementation of consumer protection; (2) The fostering of the implementation of consumer protection as referred to in paragraph (2) includes efforts to: create a business climate and develop a healthy relationship between business actors and consumers; development of non-governmental consumer protection organizations; increasing the quality of human resources and increasing research and development activities in the field of consumer protection; Further provisions regarding the development of consumer protection are regulated by a Government Regulation.

8 Rachmadi Usman, Material Law, Sinar Grafika, Jakarta, 2011, page. 295. 
Contract justice can be seen in an agreement when both parties reach an agreement to bind themselves together without any pressure from the other party, in this case the contract is carried out voluntarily.

Credit agreement at the bank, the position of the customer when they want to apply for credit, they must follow the rules that have been made by the bank, without any room for negotiation, it can be related to interest, payment methods or other provisions. In addition, this bargaining position is also related to the ability of the parties related to the economic situation they have.

Negotiation is an important thing in an agreement, by negotiating, both parties can find out the rights and obligations to be carried out. Negotiations in an agreement arise because the parties have their own goals that they want to aim at, so that with these negotiations it is hoped that an agreement can be reached.

The principle of negotiation itself is contained in the supply and demand (aanbod en aanvaarding), in the supply and demand the parties can exchange ideas and wishes for a specific purpose. Negotiations carried out in an agreement can also avoid one-sided contracts, this is contrary to the principle of proportionality and the principle of balance, in which both principles state that the existence of balance for the parties is an initial step in creating contracted justice.

Standard credit agreements in banking are a common thing. This makes it easier when signing a credit agreement. Consumers or customers as borrowers generally just need to sign without reading the details of the agreement. Problems will arise when the credit is experiencing problems and in the end there must be a dispute in court.

According to Mariam Darus Badrulzaman, the characteristics of the exonation clause are: the contents are determined unilaterally by the seller (entrepreneur) whose position is relatively stronger than that of the buyer; the buyer (consumer) in no way determines the contents of the agreement; driven by his needs the buyer (consumer) is forced to accept the agreement; written form; prepared in advance in bulk or individually. ${ }^{9}$

In the contents of the standard agreement above, it is clear that the creditor forces his will to be approved and followed by the debtor as the consumer to override the provisions of Article 1266 of the Civil Code which aims to protect parties who are in a weak position (debtors) in the agreement and also limit the authority of strong parties. (creditors). As for this Article 1266 of the Civil Code: The condition for invalidation is considered to be always included in a reciprocal agreement, if one of the parties does not fulfill its obligations. In such a case the agreement is not null and void, but the cancellation must be requested to the Court. This request must also be made, although the cancellation conditions regarding non-fulfillment of obligations are stated in the agreement. If the conditions for cancellation are not stated in the agreement, the

9 Sri Gambir Melati Hatta, 2000, Beli-Sewa Sebagai Perjanjian Tak Bernama: Pandangan Masyarakat dan Sikap Mahkamah Agung",Cetakan ke-3, Alumni, Bandung. page. 149-151 
Judge by observing the circumstances, at the request of the respondent, is free to give a period of time to fulfill the obligations, but that period cannot be more than one month.

The standard agreement in the bank credit agreement proves that the debtor in the Credit Agreement is the less fortunate party / is in a weak position, that is, with more obligations than their rights. In relation to the substance of the agreement between creditors and debtors in the banking credit agreement, it appears that the bank credit agreement in the form of a standard agreement does not or does not fulfill a sense of justice.

The meaning of this article is that the parties who enter into an agreement must comply with the provisions of this article, the parties may not cancel the agreement based on their own will for reasons of not fulfilling the obligations between one of the parties. The desire to cancel an agreement must be submitted to the Court. The wish to cancel must also be made even though the conditions for cancellation regarding nonfulfillment of the obligations are stated in the agreement. If the creditor continues to force his will to take the object of the agreement without a court order, the agreement ends immediately, the debtor is free from future responsibilities, and can claim back from the creditor for all that the debtor has paid in advance based on the agreement. ${ }^{10}$

The use of standard clauses in an agreement arises from the needs that exist in the community itself, that in a business relationship that requires a deed that is quite complicated and costs a lot of money, with the standard clause it is expected to cut the operational costs needed and shorten the time.

\section{CONCLUSION}

Fairness in the credit agreement with the existence of standard clauses, namely that each party (creditors and debtors) must agree as stated in the Credit Agreement, namely through the fair and free exchange of performance implementation, because an unbalanced agreement will greatly harm one of the parties and therefore will very touching the sense of justice in society. The standard agreement made by the bank, apart from not contradicting the law, must also uphold the sense of justice and balance of the parties. Negotiations carried out in an agreement can also avoid onesided contracts, and this is one of the first steps in creating a fair contract. Before signing the agreement, the parties should study in detail the clauses contained in the agreement, or at least find out the legal basis used in the event of undesirable things. 


\section{BIBLIOGRAPHY}

\section{Book:}

Abdul Kadir Muhammad. 2006. Legal Agreement. Alumni. Bandung; Jakarta; . 2004. Legal and Research Method, Citra Aditya Bakti,

Ahmadi Miru dan Sutarman Yodo, 2004. Legal Consume Protection, Raja Grafindo Persada. Jakarta;

Alimuddin Siregar. 2019. Pornograhy Law Regulation, Scopindo Media Pustaka, Surabaya;

Eva Zulfa Nailufar, 2014, Just Wages According to Islamic Law, Kajian UMP DKI, A-Empat. Jakarta;

Gatot Supramono. 2009. Banking and Credits Issues, Rineka Cipta, Jakarta;

Gunawan Widjaja dan Ahmad Yani. 2003. Law Regarding Consumer Protection, Third Press. Gramedia. Jakarta;

H.Man. S.Sastrawidjaja, 2005, Interest Until Commercial Law. Alumni. Bandung;

Imam Sjahputra, Consumer Protectionin Electronic Transactions. Alumni. Bandung;

Lexy J. Moleong. 1998. Qualitative Research Methodology, Remaja Rosdakarya Offset, Bandung;

Munir Fuady, 2003, Contract Law (From a Business Law Point of View), Second Book. Citra Aditya Bakti. Jakarta;

Ronny Hanitiyo Soemitro. 1990. Legal Research Methodology, Ghalia Indonesia Jakarta;

Salim Hs, 2007, Contact Design and Memorandum of Understanding (MoU). Sinar Grafika. Jakarta;

Sri Gambir Melati Hatta, 2000, Purchase-Lease as an Unnamed Agreement: Public Views and Attitudes of the Supreme Court, 3rd Printing, Alumni. Bandung;

Sutan Remy Sjahdeini. 1993. Freedom of Contract and Balanced Protection for Parties in Bank Credit Agreements in Indonesia, Institut Bankir Indonesia. Jakarta;

\section{Legislation:}

Code of Civil Law

\section{Journal :}

Fatma Paparang, Implementation of Fidusia Guarantee in Lending in Indonesia, Jurnal LPPM Bidang Ekosobud, Volume 1 Number 2, 2014;

Firya Oktaviarni, Application of Standard Clauses in Consumer Financing Agreements According to Law Number 8 of 1999 concerning 
Consumer Protection, Jurnal IImu Hukum, Volume 6, Number 2, 2015;

Ida Ayu Made Widyari, I Nyoman Shirta, I Made Sarjana, Registration Legal Due Fidusia Guarantee In Online System, Acta Comitas Journal, Volume 2 Number 2, 2017;

Johny Khoesoema Hioe, Anis Mashdurohatun, Gunarto, Irwan Jasa Tarigan, Reconstruction of Pretrial Institution Function in Supervising Investigator Authorization Based on Justice Value with Moderating Role of Supply Chain Management, International Journal of Supply Chain Management, Vol. 9, Number 3, June 2020;

Jonneri Bukit, Made Warka dan Krisnadi Nasution, The existence of the principle of balance in consumer contracts in Indonesia, Jurnal Ilmu Hukum, Volume 14, Number 28 Agustus 2018;

Junaidi Abdulla, Guarantee in Fidusia in Indonesia (Registration and Execution Procedures, Journal Bisnis, Volume 4 Number 2, 2016;

Khifni Kafa Rufaida, Legal Review of The Execution of Fidusian Security Objects Without Legal Executorial Title, Refleksi Hukum Journal, Volume 4 Number 1, 2019;

Lathifah Hanim, MS.Noorman, Settlement of Bank Credit Agreements as a Result of Force Majeure Due to the Yogyakarta Earthquake, Jurnal Pembaharuan Hukum, Volume III Number 2 Mei - Agustus 2016;

M. Yasir, Legal Aspect of Fiduciary Guarantee, Salam Journal, Volume 3 Number 1, 2016;

M.Roesli, Sarbini, Bastianto Nugroho, Position of Standard Agreement about Freedom of Contracting Principle, Jurnal IImu Hukum, Volume 15 Nomor 1 Februar7 2019-July 2019;

Rindia Fani Kusumaningtyas, Development of Fiduciary Guarantee Law Relating to Copyright as an Object of Fiduciary Guarantee, Pandecta Journal, Volume 11, Number 1, 2016;

Soegianto, Diah Sulistyani, Muhammad Junaidi, Execution of Fidusian Warranties in The Study of Law Number 42 of 1999 Concerning Fidusian Securities, Ius Constituendum Journal, Volume 4 Number 2, 2019;

Yanti Malohing, Position of Standard Agreement Relating to the Principle of Freedom of Contract, Lex Privatum, Volume V Number 4, June 2017;

\section{Internet :}

Robert A. Hillman \& Jeffrey J. Rachlinski, "Standard-Form Contracting in the Electronic Age", <http://ssrn.com/abstract=287819\&gt 